\title{
Cefepime-induced jaw myoclonus
}

回

Supplemental data at Neurology.org
Neurotoxicity resulting in reversible encephalopathy with myoclonus has been increasingly recognized as a complication of cefepime, especially in patients with renal insufficiency. ${ }^{1,2}$ We report 2 cases of jaw myoclonus (video on the Neurology ${ }^{\circledR}$ Web site at Neurology.org) that occurred within 48 hours of administration of cefepime. Both patients had preexisting renal insufficiency, and both experienced resolution of the myoclonus within 24 hours of discontinuation of the drug. Given the discomfort of jaw myoclonus and the inability to take oral nutrition as a result, rapid diagnosis and immediate drug discontinuation are crucial.

\section{Sina Khasani, $M D$}

From Maimonides Medical Center, Brooklyn, NY, and Albert Einstein College of Medicine, Bronx, NY. Study funding: No targeted funding reported.

Disclosure: The author reports no disclosures relevant to the manuscript. Go to Neurology.org for full disclosures.

Correspondence to Dr. Khasani: skhasani@maimonidesmed.org

1. Fugate JE, Kalimullah EA, Hocker SE, Clark SL, Wijdicks EF, Rabinstein AA. Cefepime neurotoxicity in the intensive care unit: a cause of severe, underappreciated encephalopathy. Crit Care 2013;17:R264. doi: 10.1186/cc13094.

2. Hocker S, Rabinstein AA. Cefepime neurotoxicity can mimic postanoxic coma with myoclonic status epilepticus. Neurol Clin Pract 2011;1:73-74. 


\section{Neurology}

\section{Cefepime-induced jaw myoclonus \\ Sina Khasani}

Neurology 2015;84;1183

DOI 10.1212/WNL.0000000000001365

\section{This information is current as of March 16, 2015}

\section{Updated Information \& Services}

\section{Supplementary Material}

\section{References}

Subspecialty Collections

\section{Permissions \& Licensing}

\section{Reprints}

including high resolution figures, can be found at: http://n.neurology.org/content/84/11/1183.full

Supplementary material can be found at: http://n.neurology.org/content/suppl/2015/03/14/WNL.0000000000001 365.DC1

This article cites 2 articles, 1 of which you can access for free at: http://n.neurology.org/content/84/11/1 183.full\#ref-list-1

This article, along with others on similar topics, appears in the following collection(s):

All Clinical Neurology

http://n.neurology.org/cgi/collection/all_clinical_neurology All Epilepsy/Seizures

http://n.neurology.org/cgi/collection/all_epilepsy_seizures All Toxicology

http://n.neurology.org/cgi/collection/all_toxicology

Myoclonus

http://n.neurology.org/cgi/collection/myoclonus

Information about reproducing this article in parts (figures,tables) or in its entirety can be found online at:

http://www.neurology.org/about/about_the_journal\#permissions

Information about ordering reprints can be found online: http://n.neurology.org/subscribers/advertise

Neurology ${ }^{\circledR}$ is the official journal of the American Academy of Neurology. Published continuously since 1951, it is now a weekly with 48 issues per year. Copyright () 2015 American Academy of Neurology. All rights reserved. Print ISSN: 0028-3878. Online ISSN: 1526-632X.

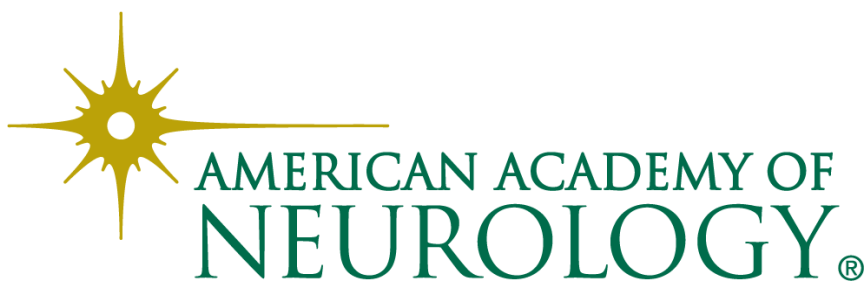

